\title{
Status prawny konsumenta jako strony umowy o kredyt indeksowany/ denominowany do franka szwajcarskiego
}

\section{Wprowadzenie}

Celem artykułu jest analiza prezentowanych w doktrynie, a także polskim i unijnym orzecznictwie poglądów w zakresie traktowania strony umowy kredytowej jako konsumenta. Problematyka dotyczy tych sytuacji, gdy sąd w trakcie procesu bada umowę kredytu indeksowanego/ denominowanego do franka szwajcarskiego (CHF) w celu dokonania kontroli indywidualnej w zakresie niedozwolonych postanowień umownych. Kwestionowany w praktyce sądowej status konsumenta jako strony umowy kredytu bankowego indeksowanego/denominowanego do franka szwajcarskiego jest modelowym przykładem uzasadniającym sens istnienia szczególnych uregulowań chroniących konsumenta przed „wyzyskiem" ze strony silniejszego profesjonalisty. Gospodarka rynkowa w swoim idealistycznym założeniu powinna regulować się sama. Prawo podaży i popytu powinno gwarantować prawidłowe funkcjonowanie rynku i bezpieczeństwo obrotu podmiotów w nim uczestniczących. Niestety, rynek podlega zakłóceniom, których część jest generowana przez samych jego uczestników dążących do maksymalizowania zysków. Ustawodawca, chcąc przeciwdziałać takim tendencjom, stworzył wiele regulacji prawnych, które w swoim założeniu mają prowadzić do tego, aby zasady uczciwej konkurencji i równowagi stron były przestrzegane. Trafnie ujął to T. Pajor: "Motywem tradycyjnie wysuwanym na pierwszy plan, zwłaszcza w krajowych porządkach prawnych, jest strukturalna nierównowaga pozycji stron w stosunkach tego rodzaju. Prawodawcy 
przyjmują założenie, że wobec przedsiębiorcy, profesjonalisty, konsument jest zawsze stroną słabsza, tak ze względu na stopień swych kompetencji i dostępu do informacji, jak i możliwości ekonomiczne. Dlatego wymaga on zwiększonej ochrony prawnej, która powinna tę nierównowagę wobec przedsiębiorcy niwelować"1. Po wejściu Polski do Unii Europejskiej staliśmy się członkiem wspólnego rynku, który w szczególny sposób traktuje konsumentów. Warto choćby wskazać na Dyrektywę Parlamentu Europejskiego i Rady 2011/83/UE w sprawie praw konsumentów, zmieniającą dyrektywę Rady 93/13/EWG i dyrektywę 1999/44/WE Parlamentu Europejskiego i Rady oraz uchylającą dyrektywę Rady 85/577/EWG i dyrektywę 97/7/WE Parlamentu Europejskiego i Rady², która w art. 2 zawiera definicję konsumenta. Konsument w rozumieniu tej dyrektywy oznacza każdą osobę fizyczna, która w umowach (objętych omawianą dyrektywą) działa w celach niezwiązanych z działalnością handlową, gospodarczą, rzemieślniczą ani wykonywaniem wolnego zawodu. Tak definiowany konsument ma być uprzywilejowany w kontaktach z przedsiębiorcą w celu zapewnienia faktycznej równowagi stron i zniwelowania przeważającej pozycji przedsiębiorcy-profesjonalisty. Dysproporcja ta jest szczególnie widoczna na przykładzie stosunków konsument-bank, gdzie osoba fizyczna musi się przeciwstawiać wyspecjalizowanej korporacji zorientowanej na optymalizację zysku. Praktyka sądowa pokazuje, że przy okazji sporów pomiędzy bankiem a kredytobiorcą kredytu indeksowanego/denominowanego do CHF powstaje wiele wątpliwości co do rozumienia pojęcia konsumenta. Jest to o tyle istotne, że status konsumenta przesądza o możliwości stwierdzenia postanowień umowy kredytowej za niedozwolone. Należy w tym miejscu podkreślić, że kredyty denominowane/indeksowane, których dotyczy niniejszy artykuł, zawierane były przede wszystkim w latach 2005-2010, natomiast spory wynikłe z tych umów toczą się obecnie. Implikuje to, oczywiście, konieczność zastosowania do analizy przepisów obowiązujących w dacie zawierania umów. Należy też zauważyć, że nie istnieje, niestety, definicja legalna ani kredytu indeksowanego do waluty obcej, ani kredytu denominowanego w tej walucie. Trafnie zdefiniowała je A. Jurkowska-Zeidler, stwierdzając, że „[w] przypadku kredytu denominowanego w walucie obcej kwota kredytu na umowie jest wyrażona w walucie obcej, ale kredyt jest wypłacany w złotych po kursie z dnia

${ }^{1}$ T. Pajor, Komentarz do art. $22^{1}$ k.c., pkt 2, w: Kodeks cywilny. Komentarz. Część ogólna, pod red. P. Księżaka, M. Pyziak-Szafnickiej, Warszawa 2014, s. 251.

2 Dz.Urz. UE L 304 z 22 XI 2011 r., s. 64. 
uruchomienia. [...] Z kolei kredyt indeksowany w stosunku do waluty obcej jest de facto rodzajem kredytu w złotych, ale waloryzowanym do kursu waluty obcej"3. Rozróżnienie to jest jednak ambiwalentne dla statusu konsumenta. Przedmiotem rozważań będą więc umowy kredytowe, kredytów hipotecznych zawarte zgodnie z art. 69 ustawy prawo banko$w^{4}{ }^{4}$ w brzmieniu sprzed nowelizacji ustawą o zmianie ustawy - Prawo bankowe oraz niektórych innych ustaw ${ }^{5}$ (tzw. ustawa antyspreadowa).

\section{Definicja legalna konsumenta}

W systemie prawa wyróżnia się pojęcie konsumenta ze względu na strukturalną nierówność, jaka występuje w jego relacjach z przedsiębiorcą ${ }^{6}$. Ustawodawca definicję konsumenta umieścił w Kodeksie cywilnym ${ }^{7}$. Definicja ta, zawarta $\mathrm{w}$ art. $22^{1}$ k.c., pozostaje $\mathrm{w}$ zgodzie $\mathrm{z}$ definicją określoną w art. 2 pkt 1 Dyrektywy 2011/83 oraz art. 2 lit. d Dyrektywy 2002/65/WE Parlamentu Europejskiego i Rady z dnia 23 września 2002 r. dotyczącą sprzedaży konsumentom usług finansowych na odległość oraz zmieniającą dyrektywę Rady 90/619/EWG oraz dyrektywy 97/7 WE i 98/27/WE, z uwzględnieniem pewnych różnic językowych. W myśl art. $22^{1}$ k.c. konsumentem jest osoba fizyczna dokonującą z przedsiębiorcą czynności prawnej niezwiązanej bezpośrednio z jej działalnością gospodarczą lub zawodową. Tak więc "zawarta w art. $22^{1}$ k.c. definicja konsumenta łączy kryterium podmiotowe i przedmiotowe, wskazując, że za konsumenta może być uważna tylko osoba fizyczna znajdująca się w sytuacji prawnej, polegającej na dokonywaniu czynności cywilnoprawnej, mającej wywołać skutek prawny w jej relacji z przedsiębiorca, a ta czynność nie może być bezpośrednio związana z prowadzoną przez tę osobę działalnością gospodarczą lub zawodową"8.

${ }^{3}$ A. Jurkowska-Zeidler, Asymetria ryzyka a zasada sprawiedliwości społecznej na tle problemu kredytów we frankach szwajcarskich, "Gdańskie Studia Prawnicze" 2016, t. XXXV, pod red. J. Zajadły, s. 131.

${ }^{4}$ Ustawa z dnia 29 VIII 1997 r. - Prawo bankowe (tekst jedn. Dz.U. 2017, poz. 1876).

${ }^{5}$ Ustawa z dnia 29 VII 2011 r. o zmianie ustawy - Prawo bankowe oraz niektórych innych ustaw (Dz.U. Nr 165, poz. 984).

${ }^{6}$ T. Czech, Prawa konsumenta. Komentarz, Warszawa 2017, s. 16.

${ }^{7}$ Ustawa z dnia 23 IV 1964 r. - Kodeks cywilny (tekst jedn. Dz.U. 2017, poz. 459), dalej "k.c.".

${ }^{8}$ T. Sokołowski, Komentarz do art. $22^{1}$ k.c., pkt 1, w: Kodeks cywilny. Komentarz. Część ogólna, t. 1, pod red. A. Kidyby, Warszawa 2012, s. 114. 
Definicja konsumenta jest określona ze względów funkcjonalnych. „W literaturze trafnie zwrócono uwagę na funkcjonalny charakter powyższej definicji"9. Komentarze do Kodeksu cywilnego wyróżniają cztery kluczowe elementy definicji: „konsumentem może być tylko osoba fizyczna, po drugie, musi ona dokonywać czynności prawnej, po trzecie, czynność ta pozostaje w określonej relacji z rolą społeczną tej osoby, a po czwarte, adresatem oświadczenia woli jest przedsiębiorca"10. Szczególną ochronę konsumentów przewiduje również Konstytucja Rzeczypospolitej Polskiej ${ }^{11}$. W art. 76 stanowi, że "władze publiczne chronią konsumentów, użytkowników i najemców przed działaniami zagrażającymi ich zdrowiu, prywatności i bezpieczeństwu oraz przed nieuczciwymi praktykami rynkowymi". Trybunał Konstytucyjny wypowiadał się wielokrotnie na temat konsumentów. Przykładowo można tu zacytować tezę, zgodnie z którą ustrojodawca przyjął za pewnik, że konsument jest słabszą stroną stosunku prawnego i $\mathrm{z}$ tego powodu wymaga ochrony, a więc pewnych uprawnień, które doprowadziłyby do przynajmniej względnego zrównania pozycji kontrahentów. Uprawnieniom konsumenta odpowiadają pewne obowiązki drugiej strony sprzedawcy czy usługodawcy. Łącznie zaś owe uprawnienia jednej i obowiązki drugiej strony mają zrekompensować konsumentowi niepełną możliwość skorzystania z zasady autonomii woli stron umowy ${ }^{12}$. W literaturze przedmiotu wskazuje się, że ochrona konsumenta nie ma na celu jego faworyzowania, ale zapewnienie mu faktycznej równowagi stron. Bardzo trafnie ujęła to E. Łętowska, stwierdzając, że "ochrona konsumenta nie oznacza [...] protekcjonistycznego faworyzowania konsumenta przez władzę, lecz działania na rzecz zrekompensowania braku jego wiedzy i orientacji, wywołanych masowością produkcji i obrotu w ogólności. Nie chodzi o przywilej, lecz o zrównoważenie utraconych szans, powrót do idei spoczywającej u założeń swobody umów, o przywrócenie mu warunków oceny sytuacji rynkowej [...]. Przedsięwzięcia i instrumenty służące ochronie konsumenta nie mają [...] na celu «dania» mu czegoś dodatkowego, ale [...] przywrócenie

${ }^{9}$ P. Kukuryk, Definicja konsumenta w kodeksie cywilnym (obecnym i przyszłym) w kontekście najnowszych unijnych dyrektyw konsumenckich, "Przegląd Prawa Handlowego" 2014, nr 5, s. 18.

${ }^{10}$ T. Sokołowski, Komentarz do art. $22^{1}$ k.c., pkt 2.

${ }^{11}$ Konstytucja Rzeczypospolitej Polskiej z dnia 2 IV 1997 r. (Dz.U. Nr 78, poz. 483 ze zm.), dalej „Konstytucja RP”.

${ }^{12}$ Wyrok Trybunału Konstytucyjnego (TK) z 2 XII 2008 r., sygn. K 37/07, OTK-A 2008/10, poz. 172 . 
równości szans, traconych wraz z rozwojem nowoczesnej produkcji, handlu czy marketingu. Dlatego [...] «ochrona konsumenta» to [...] instrument walki o rynek prawdziwie wolny - dla wszystkich jego uczestników, czynnych i biernych"13.

Warto wspomnieć, że ustawa o ochronie konkurencji i konsumentów odwołuje się do definicji przyjętej w Kodeksie cywilnym. Ustawa o ochronie konkurencji i konsumentów ${ }^{14}$ nie tworzy własnej definicji konsumenta. Odwołuje się ona wprost w art. 4 pkt 12 do przepisów Kodeksu cywilnego. Ustawa o prawach konsumenta ${ }^{15}$ nie formułuje również własnej definicji konsumenta. Operuje jednak tym pojęciem, które należy odnosić także do definicji kodeksowej.

\section{Wzorzec konsumenta i wartościowanie konsumenta}

Prawo unijne oraz polskie prawo cywilne skłania się ku stosowaniu modelu konsumenta świadomego, czyli wyedukowanego, analizującego posiadane informacje (tzw. konsument oświecony), nawet jeśli w rzeczywistości dana osoba takich warunków nie spełnia. Taki model jest realizowany w szczególności poprzez nałożenie na przedsiębiorcę obowiązku dostarczenia konsumentowi informacji (tzw. ochrona przez informację). Zasada ta, niestety, jest nadinterpretowywana przy okazji sporów dotyczących tzw. kredytów frankowych. Ponieważ przeważająca część powództw zmierza do udowodnienia abuzywności poszczególnych postanowień umownych $\mathrm{w}$ umowach kredytowych, dlatego zastosowanie znajduje tu art. $385^{1}$ k.c. Skutkiem jego zastosowania jest to, że postanowienia umowy, które nie były uzgadniane indywidualnie $z$ konsumentem ( $w$ drodze indywidualnej negocjacji), nie wiążą go (są wobec konsumenta bezskuteczne), jeżeli kształtują jego prawa i obowiązki w sposób sprzeczny z dobrymi obyczajami, rażąco naruszając jego interesy (niedozwolone postanowienia umowne). Argumentacja banków zmierza do wykazania, że osoba fizyczna zawierająca z bankiem umowę kredytu była "konsumentem oświeconym”, a więc miała (lub powinna mieć) pełną świadomość treści oraz skutków zawieranej umowy. Czy udowodnienie faktu, iż konsument wiedział o wadliwości

${ }^{13}$ E. Łętowska, Prawo umów konsumenckich, Warszawa 1999, s. 19.

${ }^{14}$ Ustawa z dnia 16 II 2007 r. o ochronie konkurencji i konsumentów (tekst jedn.

Dz.U. 2017, poz. 229).

${ }^{15}$ Ustawa z dnia 14 V 2014 r. o prawach konsumenta (tekst jedn. Dz.U. 2017, poz. 683). 
zapisów umowy, wyłącza abuzywność tych wadliwych postanowień umownych, "bo klient wiedział i godził się na zapisy”? Należy stanowczo sprzeciwić się takiej tezie, gdyż nie znajduje ona jakiegokolwiek oparcia w obowiązującym prawodawstwie. Co więcej, forsowanie teorii przeciwnej w zasadzie zaprzeczyłoby istocie koncepcji niedozwolonych postanowień umownych. Trudno zgodzić się z praktyką wielu sądów, dokonujących oceny świadomości konsumenta w trakcie zawierania umowy i przyjmujących, że im ta świadomość jest wyższa, tym skutki jego działania są większym usprawiedliwieniem dla abuzywnych zapisów umownych. Mamy w tym przypadku do czynienia z finezyjną próbą rozmycia odpowiedzialności przedsiębiorcy, któremu zarzucono stosowanie niedozwolonych zapisów umownych lub, mówiąc precyzyjniej, z próbą przeniesienia części odpowiedzialności za te zapisy na "oświeconego konsumenta”. Konsumenta, który swoją „zgodą" na abuzywne zapisy umowy, w mniemaniu banku, w jakimś zakresie je konwalidował. Taką retorykę spotyka się w uzasadnieniach do wyroków. Nawet Sąd Najwyższy (SN) wypowiedział się w podobnym duchu: "Z definicji zawartej w art. $22^{1}$ k.c. wynika, że za konsumenta uważa się osobę fizyczną dokonującą czynności prawnej niezwiązanej bezpośrednio z jej działalnością gospodarczą lub zawodową. Pominięte zostało wskazanie osoby, z którą ma być dokonana przez konsumenta czynność prawna. W zasadzie chodzi o zróżnicowanie sytuacji prawnej tych dwóch podmiotów, które spowodowane jest przyznaniem słabszej ekonomicznie, społecznie i organizacyjnie stronie umowy silniejszej pozycji, chroniącej ją przed nieuczciwymi praktykami rynkowymi. Powołany przepis prawny nie wyznacza cech osobowych podmiotu uważanego za konsumenta, takich jak wymagany zakres wiedzy i doświadczenia w obrocie, stopień rozsądku i krytycyzmu wobec otrzymywanych informacji handlowych. Określenie tych przymiotów następuje w toku stosowania przepisów dotyczących ochrony konsumentów. Na ogół przyjmowany jest wzorzec konsumenta rozważnego, świadomego i krytycznego, który jest w stanie prawidłowo rozumieć kierowane do niego informacje. Nie ma podstaw do przyznania konsumentowi tak uprzywilejowanej pozycji, w której byłby zwolniony z obowiązku przejawiania jakiejkolwiek staranności przy dokonywaniu oceny treści umowy, którą zamierza zawrzeć"16. Stanowisko SN wydaje się jednak nie do pogodzenia z ugruntowaną wykładnią art. $22^{1}$ k.c., gdyż dopisywałoby do definicji konsumenta cechy,

${ }^{16}$ Wyrok SN z 13 VI 2012 r., sygn. II CSK 515/11, LEX nr 1231312. 
których ustawodawca nie zakładał. Samo stanowisko SN definiujące wzorzec konsumenta oświeconego jest co do zasady słuszne, natomiast jego zastosowanie w konkretnych sprawach może budzić wątpliwości. Co gorsza, ten rodzaj argumentacji jest powoływany w orzeczeniach sądów niższych instancji. Wzorzec konsumenta oświeconego powinien być wykorzystywany tylko i wyłącznie do badania stopnia możliwości pojmowania i percepcji w zakresie zrozumienia norm prawnych wynikających z treści umów czy ogólnych warunków umów przedstawionych konsumentowi. Parafrazując, konsument powinien otrzymać dokumenty napisane w taki sposób i przy użyciu takiego języka, żeby móc je zrozumieć w stopniu wystarczającym do świadomego zawarcia umowy. W tym miejscu musi się pojawić jeszcze jedno założenie. Nie ma znaczenia dla oceny prawnej statusu konsumenta analiza jego rzeczywistych cech osobowych (doświadczenia życiowego, wykształcenia itd.). Jeśli umowa (lub inny dokument) jest przeznaczony dla konsumenta, powinien być on jasny i czytelny dla abstrakcyjnego konsumenta oświeconego, a niekoniecznie dla konkretnego konsumenta dokonującego czynności prawnej. A contrario konsument nie powinien się zasłaniać tym, że nie zrozumiał umowy, i dowodzić, iż przedsiębiorca nie dopełnił swoich obowiązków informacyjnych, jeśli "przeciętny oświecony konsument" zrozumiałby zakres przekazu. Taki model byłby do zastosowania przy dokonywaniu interpretacji pojęcia konsumenta, zawartego w art. 385 § 2 k.c. - „Wzorzec umowy powinien być sformułowany jednoznacznie i w sposób zrozumiały". Podkreślić należy, że postanowienia niejednoznaczne tłumaczy się na korzyść konsumenta.

W tym miejscu należy poczynić bardzo ważną uwagę. Kwestia zrozumienia umowy (lub innego tożsamego dokumentu) jest czymś zupełnie innym od kwestii istnienia bądź nieistnienia klauzul abuzywnych. Klauzule niedozwolone są obiektywnie wadliwe. Logicznym uzasadnieniem tej tezy jest istnienie wszystkich mechanizmów kontroli abstrakcyjnej postanowień umownych. Podczas przeprowadzania kontroli abstrakcyjnej badaniu podlega treść wzorca umownego. W doktrynie dominuje pogląd, że treść wzorca, jako instrumentu przeznaczonego do wielokrotnego i szerszego zastosowania, powinna być ustalana z zastosowaniem metody obiektywnej ${ }^{17}$. Zastosowanie metody obiektywnej powoduje, że oceny abuzywności w trybie kontroli abstrakcyjnej dokonuje się

${ }^{17}$ R. Trzaskowski, Komentarz do art. $385^{1}$ k.c., pkt 28, w: Kodeks cywilny. Komentarz. Zobowiązania. Część ogólna, t. 3, pod red. J. Gudowskiego, Warszawa 2018, s. 293. 
poprzez badanie treści wzorca, jego transparentności oraz zgodności z klauzulami generalnymi, takimi jak np. dobre obyczaje. Przywołana powyżej ocena jest dokonywana bez uwzględnienia kontekstu indywidualnego.

Stosowanie art. $22^{1}$ k.c. w zw. z art. $385^{1} \S 2$ k.c. nie wymaga w zasadzie jakichkolwiek zabiegów wartościujących w stosunku do osoby konsumenta. Charakter klauzuli abuzywnej jest ogólny, oderwany od cech strony zawierającej umowę. Niezależnie od tego, za jakim modelem konsumenta się opowiemy, skutek będzie identyczny. Czy przyjmiemy, że konsument jest źle wyedukowany, niedbały i słabo zorientowany w otaczającym go świecie ${ }^{18}$, tzw. zwykły konsument, czy też uznamy go za konsumenta stanowczego i krytycznego, "oświeconego", korzystającego z możliwości stwarzanych mu przez akcje informacyjne i edukacyjne do niego adresowane ${ }^{19}$, czyli za konsumenta oświeconego, nie ma to żadnego znaczenia. Wadliwość klauzul niedozwolonych ma charakter bezwzględny i obiektywny. Nie zmienia w żaden sposób takiego postanowienia w umowie/ogólnych warunkach umowy to, czy będziemy analizować konsumenta jako "zwykłego" czy "oświeconego". Często w trakcie procesów sądowych banki starają się ocenić świadomość konsumenta nie tylko poprzez zastosowanie danego wzorca, ale poprzez analizę cech konkretnej osoby. Takie działanie jest pozbawione jakiejkolwiek podstawy prawnej, bo, jak wspomniano wcześniej, abuzywność zapisów umownych ma charakter obiektywny. Idąc dalej, dla oceny abuzywności nie ma znaczenia, czy konsument wiedział o wadliwości danego postanowienia lub też mógł wiedzieć. Ustawa nie nakłada na konsumenta żadnych szczególnych ani pozytywnych, ani negatywnych obowiązków zachowań dla skuteczności abuzywności konkretnego zapisu umownego. Co więcej, nawet świadoma zgoda konsumenta (czy nawet hipotetyczna sytuacja, kiedy poinformowany, że postanowienie jest niezgodne z prawem, zawiera umowę i się na ten zapis godzi świadomie i z premedytacją) nie konwaliduje abuzywności. Przedsiębiorcom nie wolno postępować $z$ konsumentami w taki sposób, by ich prawa i obowiązki ustalane były w sposób sprzeczny z dobrymi obyczajami lub rażąco naruszały ich interesy. Ten zakaz ma charakter

${ }^{18}$ M. Olczyk, Zmiana treści umowy w czasie trwania stosunku umownego między bankiem a jego klientem na przykładzie zmiany stóp oprocentowania, cz. 2, „Prawo Bankowe” 2001, nr 2, s. 75 .

${ }^{19}$ E. Łętowska, Ustawa o ochronie niektórych praw konsumentów. Komentarz, Warszawa 2001, s. 94. 
obiektywny. To, czy w roli konsumenta jest profesor prawa lub ekonomii, czy też jest to osoba z wykształceniem niepełnym podstawowym, nie ma znaczenia. Klauzula wyczerpująca przesłanki z art. $385^{1} \S 1$ k.c. będzie zawsze niedozwolonym postanowieniem umownym niezależnie od tego, jakie wykształcenie, status społeczny i doświadczenie życiowe ma druga strona kontraktu. Aby uniknąć takich wątpliwości, ustawodawca stworzył bardzo prostą i skąpą definicję konsumenta w art. $22^{1}$ k.c. Przyznanie jednostce statusu konsumenta warunkowane jest bowiem charakterem podejmowanych przez nią zachowań (wyznaczają one przedmiotowy charakter definicji ${ }^{20}$, a nie charakterem tej jednostki.

Podsumowując, jeśli status konsumenta badany jest dla potrzeb art. $385^{1}$ k.c., stosować należy wykładnię językową art. $22^{1}$ k.c. Doktrynalny spór o model wzorca konsumenta ma sens tylko w przypadku przepisów, w których trzeba dokonywać oceny z uwzględnieniem stopnia wiedzy czy świadomości konsumenta. Przykładem takiego przepisu jest art. $385 \S 2$ k.c., zgodnie z którym trzeba zbadać zrozumiałość wzorca umownego w oparciu o konkretny schemat wiedzy posiadanej przez konsumenta, a dokładniej - dany wzorzec konsumenta. Trafnie ocenił to A. Olejniczak, uznając, że "[o]cena przejrzystości (stopnia jednoznaczności i zrozumiałości wzorca) dokonywana jest in abstracto, jednak przy uwzględnieniu właściwości typowego (przeciętnego) kontrahenta, z którym proponent zawiera umowy za pomocą wzorca. Oznacza to, że wzorzec zrozumiały dla profesjonalisty może zostać uznany za niewystarczająco komunikatywny wobec konsumenta. Nie są brane pod uwagę możliwości percepcyjne konkretnego podmiotu, lecz ocena dokonywana jest według kryteriów zobiektywizowanych, przez porównanie z typem kontrahenta zgodnym z oczekiwaniami społecznymi, na przykład lekarza, przedsiębiorcy budowlanego, taksówkarza czy użytkownika telefonu komórkowego" ${ }^{\prime 2}$. Artykuł $385^{1}$ k.c. nie wymaga takiego wartościowania. Inaczej mówiąc, stwierdzenie, czy osoba fizyczna zawierająca umowę $z$ bankiem dysponowała wiedzą fachową umożliwiającą ocenę umowy czy nie, lub też zakwalifikowanie jej jako „zwykłego" lub „oświeconego" konsumenta jest czynnością bezcelową. Klauzula umowna jest lub nie jest abuzywna obiektywnie, a definicja abuzywności zupełnie pomija aspekt podmiotowy w tym zakresie. Stopień świadomości prawnej czy obycia osoby zawierającej z bankiem umowę nie działa ani na plus, ani

${ }^{20}$ P. Kukuryk, op. cit., s. 18.

${ }^{21}$ A. Olejniczak, Komentarz do art. 385 k.c., pkt 6, w: Kodeks cywilny. Komentarz. Zobowiązania - część ogólna, t. 3, pod red. A. Kidyby, Warszawa 2014, s. 250. 
na minus w zakresie bycia przez tę osobę konsumentem. O fakcie bycia konsumentem świadczy to, że osoba ta jest osobą fizyczna, dokonującą czynności prawnej w zakresie niebędącym w bezpośrednim związku z jej działalnością gospodarczą czy zawodową.

Można by się w tym miejscu, na marginesie wcześniejszych rozważań, zastanowić, czy próby wartościowania kredytobiorców ze względu na ich wykształcenie, wiedzę i doświadczenie życiowe nie stanowią nadużycia praw podstawowych. Artykuł 32 Konstytucji RP zawiera zasadę równości oraz zakaz dyskryminacji. Zgodnie z tymi normami wszyscy są wobec prawa równi. Wszyscy mają prawo do równego traktowania przez władze publiczne oraz nikt nie może być dyskryminowany w życiu politycznym, społecznym lub gospodarczym z jakiejkolwiek przyczyny. Temat ten bardzo trafnie został podsumowany przez S. Kalusa: „powodem ochrony konsumenta jest na ogół jego słabsza pozycja wobec przedsiębiorcy, jednakże bez znaczenia dla objęcia tym pojęciem osoby fizycznej jest to, czy w istocie charakteryzuje się ona brakiem wiedzy w przedmiocie przysługujących jej praw jako kontrahentowi przedsiębiorcy lub co do zagadnień dotyczących przedmiotu umowy z przedsiębiorcą. Nawet osoba, która ma wysoką wiedzę o przedmiotach lub usługach świadczonych jej przez przedsiębiorcę, jest konsumentem, jeżeli tylko dokonuje transakcji mieszczących się poza zakresem jej działalności gospodarczej czy zawodowej, to jest w rozumieniu tego przepisu konsumentem i korzysta z odpowiedniej ochrony"22.

\section{Okoliczności wpływające na status konsumenta}

Kwestia umiejscowienia w czasie statusu konsumenta wydaje się oczywista i poza sporem. Jednak z praktyki procesowej wynika, że wcale tak nie jest. Wielokrotnie pozwane banki próbują podważać status konsumenta poprzez powoływanie się na wydarzenia sprzed daty zawarcia umowy kredytu będącej przedmiotem sporu oraz na wydarzenia, które zaistniały po dacie zawarcia kredytu w trakcie jego wykonywania. Przykładowo, pozwane banki wywodzą z faktu zawarcia przez kredytobiorcę innej wcześniejszej umowy kredytu fakt, że miał on jakąś dodatkową szczególną wiedzę i świadomość w zakresie sposobów przeliczania kwoty kredytu na CHF oraz następczo rat kredytowych.

22 S. Kalus, Komentarz do art. $22^{1}$ k.c., pkt 6, w: Kodeks cywilny. Komentarz. Część ogólna (art. 1-125), t. 1, pod red. M. Frasa, M. Habdas, Warszawa 2018, s. 100. 
Z kolei w zakresie wydarzeń następujących po dacie zawarcia kredytu pozwane banki podnosza, iż np. kredytobiorca wynajął po pięciu latach kredytowany lokal i jest to działalność gospodarcza dyskwalifikująca go jako konsumenta pięć lat wcześniej przy zawieraniu umowy. Abstrahując w tym miejscu od sensowności tych zarzutów i ich możliwości wpływania na status konsumenta (co zostanie omówione w dalszej części opracowania), należy się zastanowić, czy i jak wydarzenia przeszłe i przyszłe (w stosunku do daty zawarcia umowy kredytu) mogą wpływać na status konsumenta osoby zawierającej kredyt.

Zgodnie $\mathrm{z}$ art. $22^{1}$ k.c. za konsumenta uważa się osobę fizyczną dokonującą z przedsiębiorcą czynności prawnej niezwiązanej bezpośrednio z jej działalnością gospodarczą lub zawodową. W zakresie tej definicji bycie przez powoda osobą fizyczną nie budzi wątpliwości. Użycie imiesłowu przymiotnikowego czynnego - "dokonującą" - implikuje, że chodzi o czynność prawną teraźniejsza, czyli taka, która odbywa się w danej chwili. Jest ona jednoznacznie dokonywana. Na tę chwilę (dokonywania czynności prawnej) należy badać status konsumenta. Konsumentem się nie jest, konsumentem się bywa w danych ściśle określonych okolicznościach. Cytując za Z. Radwańskim, „każda osoba fizyczna nie tylko ma potencjalną właściwość wystąpienia w roli konsumenta, ale rzeczywiście rolę tę realizuje"23. Bez związku z każdą prowadzoną sprawa, z czysto logicznego i formalnego punktu widzenia, będzie więc poddawanie analizie wszystkich tych faktów, które miały miejsce zarówno przed zawarciem umowy, jak i po nim. Nie sa one w stanie ani odebrać, ani nadać powodowi statusu konsumenta. Jeśli kredytobiorca $\mathrm{w}$ dniu zawierania umowy kredytowej z pozwanym był konsumentem - spełniał na ten moment przesłanki określone $\mathrm{w}$ art. $22^{1}$ k.c., to jest to fakt niezmienny. Zasada ta dodatkowo (w odniesieniu do wpływu czynności przyszłych na fakty przeszłe) jest emanacją ogólnej zasady prawa cywilnego lex retro non agit.

Aby czynność osoby fizycznej uznać za czynność konsumenta, czynność prawna musi być niezwiązana bezpośrednio z działalnością gospodarczą lub zawodową tej osoby. Wykonywanie czynności będącej realizacją prowadzonej działalności gospodarczej lub wykonywaniem np. wolnego zawodu (radca prawny, lekarz itd.) dyskwalifikuje takie działanie jako działanie konsumenta z podmiotem gospodarczym i każe je traktować jako współdziałanie podmiotów gospodarczych oceniane

${ }^{23}$ Z. Radwański, Podmioty prawa cywilnego w świetle zmian kodeksu cywilnego przeprowadzonych ustawa z dnia 14 lutego 2003 r., „Przegląd Sądowy” 2003, nr 7-8, s. 14. 
na równorzędnych dla obu stron zasadach. Ustawodawca wymaga, aby ta czynność była związana bezpośrednio z tą działalnością.

W zakresie niniejszego artykułu analizie poddano czynność prawną polegającą na zawarciu umowy kredytowej kredytu indeksowanego/denominowanego, który jest dodatkowo kredytem hipotecznym, czyli takim, którego zabezpieczeniem jest hipoteka na nieruchomości i który w przeważającej większości przeznaczony jest na sfinansowanie zakupu tejże nieruchomości. Definicja legalna umowy kredytu hipotecznego znajduje się $\mathrm{w}$ art. 3 ustawy o kredycie hipotecznym oraz o nadzorze nad pośrednikami kredytu hipotecznego i agentami ${ }^{24}$, który stanowi, że przez "kredyt hipoteczny rozumie się umowę, w ramach której kredytodawca udziela konsumentowi kredytu lub daje mu przyrzeczenie udzielenia kredytu zabezpieczonego hipoteką lub innym prawem związanym z nieruchomością mieszkalną lub przeznaczonego na sfinansowanie niezwiązanego z działalnością gospodarczą lub prowadzeniem gospodarstwa rolnego nabycia lub utrzymania: 1) prawa własności budynku mieszkalnego lub lokalu mieszkalnego stanowiącego odrębną nieruchomość, a także ich budowy lub przebudowy w rozumieniu art. 3 pkt 6 i 7 a ustawy z dnia 7 lipca 1994 r. - Prawo budowlane (Dz.U. z 2016 r. poz. 290, 961, 1165, 1250 i 2255); 2) spółdzielczego własnościowego prawa do lokalu; 3) prawa własności nieruchomości gruntowej lub jej części; 4) udziału we współwłasności budynku mieszkalnego lub lokalu mieszkalnego stanowiącego odrębną nieruchomość lub udziału w nieruchomości gruntowej". Pamiętać jednak należy, że przepis ten nie obowiązywał w dacie zawierania umów, których dotyczy niniejszy artykuł. Na marginesie można tylko dodać, iż cytowana powyżej ustawa zwiększyła dla umów kredytowych zawieranych po jej wejściu w życie (22 lipca 2017 r.) ochronę konsumenta przy zawieraniu umów kredytu hipotecznego, w szczególności w zakresie obowiązków kredytodawcy, pośrednika kredytu hipotecznego i agenta przed zawarciem umowy o kredyt hipoteczny.

Dla dokonania właściwej interpretacji art. $22^{1}$ k.c. konieczna jest wykładnia pojęć „bezpośredniego związania z działalnością gospodarczą lub zawodową". W niniejszym artykule rozważania zawężono do czynności prawnej polegającej na zawarciu umowy kredytowej mającej sfinansować nabycie nieruchomości, a także na ustaleniu, kiedy taka czynność będzie miała bezpośredni związek z działalnością gospodarczą lub zawodową. Na wstępie trzeba zauważyć, że przy zawieraniu

${ }^{24}$ Ustawa z dnia 23 III 2017 r. o kredycie hipotecznym oraz o nadzorze nad pośrednikami kredytu hipotecznego i agentami (Dz.U. poz. 819). 
umowy kredytowej podmiot deklaruje we wniosku kredytowym cel kredytowania. W bankach jest powszechną praktyka, że podmioty gospodarcze są obsługiwane rozłącznie od konsumentów. Najczęściej obsługę tę realizuje oddzielny dział banku lub dedykowany takim sprawom doradca. Wówczas nie ma mowy o statusie konsumenta i umowa zawierana jest pomiędzy dwoma przynajmniej formalnie równorzędnymi podmiotami. Bank "klasyfikuje" klienta bądź jako przedsiębiorcę, bądź jako konsumenta. Przejawem tej klasyfikacji jest żądanie zupełnie innych dokumentów do analizy zdolności kredytowej. Jednocześnie należy zauważyć, że nie chodzi tu tylko o wypisy z rejestrów przedsiębiorców. Przy kredycie udzielanym podmiotowi gospodarczemu wymagany jest praktycznie zawsze biznesplan ( $\mathrm{z}$ wyjątkiem procedur uproszczonych w kredytowaniu niewielkich kwot). W biznesplanie przedsiębiorca musi udowodnić (jeśli chce otrzymać kredyt), że zakup nieruchomości jest mu niezbędny do działalności gospodarczej i że zakup ten będzie rentowny. Kryterium przyznania kredytowania jest zdolność do generowania zysku z uwzględnieniem nowej inwestycji, a nie tylko zdolność do spłaty kredytu. Należy poczynić w tym miejscu założenie, że to bank określa na podstawie oczekiwań kontrahenta oraz celu kredytowania, czy ma do czynienia z konsumentem czy z przedsiębiorcą. Bank jest wyspecjalizowanym profesjonalista, który w sposób jasny i klarowny ustala kryteria obsługi swoich klientów ze względu na ich formę i status. Brak tu miejsca na przypadek i dowolność. To bank, a nie klient decyduje, już na etapie składania wniosku, jaką klasyfikację otrzyma - czy jako konsumenta, czy jako przedsiębiorcy. Badanie, czy kontrahent jest konsumentem, mogłoby się więc zakończyć na analizie tego, przez jaki dział banku został mu udzielony kredyt i w jakiej procedurze (linii kredytowej), ponieważ banki bardzo restrykcyjnie przestrzegają podziału na bankowość detaliczną (konsumencką) oraz korporacyjną (firmową).

O konsumenckim charakterze umowy pomocniczo może też świadczyć rodzaj kredytowanej nieruchomości. Jeśli będzie to np. prawo własności do nieruchomości lokalowej, spółdzielcze własnościowe prawo do lokalu, prawo własności do działki budowlanej, prawo własności do nieruchomości zabudowanej domem jednorodzinnym, to taki przedmiot kredytowania w zasadzie przesądza o braku gospodarczego/ zawodowego charakteru zawieranej umowy. Przeciwnie, takie watpliwości może nasuwać kredytowanie domu wielorodzinnego, lokalu użytkowego, działki rolnej itd. Powyższe dywagacje mają jednak sens 
tylko wtedy, gdy przedmiotem kredytowania jest zakup danej nieruchomości, natomiast w sytuacji, kiedy dana nieruchomość stanowi tylko zabezpieczenie (hipoteka) udzielanego przez bank kredytu, są bez znaczenia. Kredyt hipoteczny może dotyczyć finansowania nie tylko zakupu nieruchomości (choć jest tak najczęściej), a ustanowiona hipoteka na dowolnej nieruchomości jest tylko jego zabezpieczeniem. Wówczas funkcja i rodzaj nieruchomości będącej przedmiotem zabezpieczenia nie może w jakikolwiek sposób rzutować na status konsumenta.

Analizę odnoszącą się do tego, czy umowa kredytu hipotecznego związana jest bezpośrednio z działalnością gospodarczą czy zawodowa, powinno poprzedzać ustalenie w pierwszej kolejności, jaki dział banku zajmuje się sprawą: jeśli jest to dział detaliczny, a po stronie kredytobiorców mamy osoby fizyczne, to w zasadzie ich status konsumentów powinien być niepodważalny. Gdyby jednak pojawiły się jakiekolwiek wątpliwości, to należałoby przeanalizować wniosek kredytowy, w którym kredytobiorcy zadeklarowali cel, na jaki ma być wzięty kredyt. Jeśli celem jest zakup danej nieruchomości bez bliższego doprecyzowania, to zbadanie zamiaru kredytobiorców (oczywiście, na dzień zawierania umowy kredytowej) będzie mogło nastąpić tylko poprzez przesłuchanie stron na tę okoliczność. Jeśli we wniosku kredytowym cel zakupu jest określony szczegółowo, np. sformułowaniem "dla celów mieszkaniowych", "dla własnych celów mieszkaniowych", "dla zaspokojenia własnych potrzeb mieszkaniowych" - brak celu gospodarczego czy zawodowego również jest jasny i nie wymaga dalszego dowodzenia w większości sytuacji faktycznych. Sprawa się komplikuje, jeśli we wniosku kredytowym wpisano inny cel zakupu nieruchomości, a mianowicie "na wynajem”, "dla wynajmu" lub inny równoznaczny, rodzi to bowiem pytanie, czy wynajem nieruchomości mieszkaniowej jest działalnością gospodarczą.

Kolejnym problemem, który powstaje na gruncie spraw o kredyt indeksowany/denominowany do CHF, jest ustalenie, czy najem stanowi działalność gospodarczą. Na to pytanie nie da się udzielić jednoznacznej odpowiedzi. Zgodnie z art. 2 ustawy o swobodzie działalności gospodarczej ${ }^{25}$ "[d] ziałalnością gospodarczą jest zarobkowa działalność wytwórcza, budowlana, handlowa, usługowa oraz poszukiwanie, rozpoznawanie i wydobywanie kopalin ze złóż, a także działalność zawodowa, wykonywana w sposób zorganizowany i ciągły". Bardzo podobnie określa to definicja zawarta w ustawie o podatku dochodowym od osób

${ }^{25}$ Ustawa z dnia 2 VII 2004 r. o swobodzie działalności gospodarczej (tekst jedn. Dz.U. 2017, poz. 2168). 
fizycznych ${ }^{26}$. Definicja działalności w tym ujęciu uzależnia uznanie danej czynności za działalność gospodarczą od spełnienia kilku przesłanek. Trafnie ujął to Dyrektor Krajowej Informacji Skarbowej w interpretacji dotyczącej właśnie najmu: „Tak więc działalność gospodarcza to taka działalność, która prowadzona jest:

1. w celu osiągnięcia dochodu - przy czym nawet ewentualna strata będąca wynikiem tej działalności nie pozbawia jej statusu działalności gospodarczej, bowiem istotny jest sam zamiar osiągnięcia dochodu,

2. w sposób ciągły - jednakże przesłanki tej nie należy rozumieć jako konieczność wykonywania działalności bez przerwy. Istotny jest zamiar powtarzalności określonych czynności celem osiągnięcia dochodu. Przy czym o ciągłości, w przypadku najmu, nie przesądza wynajmowanie danej nieruchomości przez kilka lat, lecz powtarzalność podejmowanych działań,

3. w sposób zorganizowany - co oznacza, że podejmowane działania są podporządkowane obowiązującym regułom, normom i służą osiągnięciu celu, mają wpływ na racjonalność gospodarowania posiadanymi środkami, a tym samym uczestnictwa w obrocie gospodarczym"27.

Zdaniem tego organu działalność w postaci najmu prywatnego nie jest działalnością gospodarczą. Zgodnie $\mathrm{z}$ tą interpretacją istotna jest skala i sposób wynajmu. Jeśli nie jest to działalność główna podmiotu (nie zajmuje się tym zawodowo), to wówczas nie ma powodu, aby traktować taką działalność jako działalność gospodarczą. Podsumowując, o tym, czy najem traktować jako działalność gospodarczą czy też nie, świadczyć będzie skala prowadzonej działalności. Jeden lokal wynajmowany w sposób niezorganizowany z całą pewnością nie będzie przesądzał gospodarczego charakteru danej działalności.

Z ciekawą sytuacją będziemy mieli do czynienia, jeśli kredytobiorca wynajmie lokal w trakcie trwania umowy kredytowej, a we wniosku kredytowym deklarował zaspokajanie własnych potrzeb mieszkaniowych. Ma, oczywiście, pełne prawo tak uczynić. Należy jednak w tym miejscu rozważyć, czy takie działanie (np. pięć lat po zawarciu umowy) może mieć wpływ na status tej osoby jako konsumenta w chwili zawierania umowy kredytowej. Odpowiedź może być tylko jedna. Status konsumenta i badanie jego zamiarów określa się na moment zawarcia umowy

${ }^{26}$ Ustawa z dnia 26 VII $1991 \mathrm{r}$. o podatku dochodowym od osób fizycznych (tekst jedn. Dz.U. 2016, poz. 2032 ze zm.).

${ }^{27}$ Dyrektor Krajowej Informacji Skarbowej. Interpretacja Indywidualna 2461-IBPB-2-2.4511.145.2017.1.KK, http://ipodatkowe.pl/interpretacja-174495-2461ibpb-2-2-4511-145-2017-1-kk-sposob-opodatkowania-przychodu-z-najmu-domu-napokoje.html (dostęp: 18 V 2018). 
kredytu. To, co nastąpi później z nieruchomością, której zakup był kredytowany, jest bez znaczenia. Kredytobiorca może przecież zbyć tę nieruchomość w trakcie trwania umowy kredytowej i ta okoliczność (ani żadna inna) nie ma jakiegokolwiek wpływu na istnienie bądź nieistnienie jego statusu konsumenta w chwili zawierania umowy. W sytuacji odwrotnej, gdyby kredytobiorca kupował jako przedsiębiorca mieszkanie z przeznaczeniem na biuro, a następnie zmienił zdanie i w nim zamieszkał, można by było dowodzić, że jednak w chwili zawierania umowy był konsumentem. Taka argumentacja jest oczywiście niedorzeczna i nie zasługuje na jakąkolwiek akceptację. O statusie konsumenta przesądza tylko i wyłącznie chwila zawierania danej umowy. W rolę konsumenta się tylko wchodzi, tak samo jak w rolę przedsiębiorcy, i żadne działanie post factum nie ma mocy tego zmienić. Gdyby było inaczej, nie istniałaby jakakolwiek pewność obrotu gospodarczego. Zamiar określonego wykorzystania środków pochodzących z kredytu wynika wprost z umowy kredytowej (kredyt jest zawsze celowy), zamiar określonego wykorzystania przedmiotu kredytowania (najczęściej nieruchomości) jest przez osobę zawierającą kredyt artykułowany pośrednio. Należy go badać na dzień zawarcia umowy kredytowej. Zamiar ten bez konsekwencji dla statusu konsumenta może się zmienić w czasie. Przyjęcie w tym zakresie jakichś ograniczeń byłoby nieracjonalne. W szczególności należy zauważyć, że często konsument może być zmuszony sytuacją materialną do wynajmowania kredytowanej nieruchomości, aby móc realizować dalej swoje zobowiązania kredytowe. Przy kredytach indeksowanych/ denominowanych do $\mathrm{CHF}$, których wartość drastycznie wzrosła przy wzroście kursu miernika wartości, taka sytuacja jest często spotykana.

Ustawodawca $\mathrm{w}$ swoich ustaleniach, formułując definicję konsumenta, czyni dodatkowe zastrzeżenie w postaci wymogu, aby czynność prawna miała bezpośredni związek z działalnością gospodarczą czy zawodową. Oznacza to, że jeśli ten związek jest pośredni, to osoba dokonująca czynności prawnej ma jednak status konsumenta. Czynność konsumenta musi być nadto niezwiązana bezpośrednio z jego działalnością gospodarczą lub zawodową. Oznacza to, że osoba prowadząca taką działalność, jeśli ma korzystać z przymiotu konsumenta, musi dokonywać takiej czynności, która nie dotyczy jej własnej działalności gospodarczej lub zawodowej ${ }^{28}$. Jeszcze trafniej określił to T. Sokołowski: „może być pomocne w ustaleniu tej kwestii rozpoznanie, czy dana

${ }^{28}$ S. Kalus, Komentarz do art. $22^{1}$ k.c., pkt 4, s. 99. 
czynność nie jest typowa dla prowadzonej przez tę osobę działalności gospodarczej, co często wynika z danych zamieszczonych w ewidencji o prowadzeniu działalności gospodarczej"29. Bezpośredniość związku z prowadzoną działalnością gospodarczą czy zawodową w zakresie zawarcia umowy kredytowej na zakup nieruchomości można by więc badać tylko przez pryzmat rodzaju nabywanej nieruchomości oraz jej przeznaczenia. Jeśli podmiot gospodarczy nabywa lokal użytkowy lub nabywa mieszkanie w celu jego wynajmu i do tego zajmuje się zawodowo taką właśnie działalnością, to nie będzie on miał, rzecz jasna, statusu konsumenta. Inna sytuacja zachodzi, jeśli podmiot gospodarczy nabywa mieszkanie, w którym będzie on jako osoba fizyczna (pracownik tego podmiotu) zamieszkiwał i dodatkowo nie będzie to miało związku z prowadzoną działalnością, np. mieszkanie dla delegowanego pracownika. Takie działanie może dowodzić, że osoba fizyczna - przedsiębiorca działał jako konsument. Trudno jednak znaleźć logiczne uzasadnienie takiego działania w interesie firmy. Sytuacje takie są wobec tego niezwykle rzadkie i w zasadzie można je pominąć w praktyce orzeczniczej.

\section{Podsumowanie}

Konsument to osoba, która spełnia cztery przesłanki określone $\mathrm{w}$ art. $22^{1} \mathrm{k}$.c. Musi być to osoba fizyczna, co w zasadzie jest oczywiste i nie budzi jakichkolwiek trudności kwalifikacyjnych. Osoba ta musi dokonywać czynności prawnej z drugą strona, którą z kolei musi być przedsiębiorca. Czynność prawna (umowa) musi być niezwiązana bezpośrednio $\mathbf{z}$ działalnością gospodarczą czy zawodową tej osoby fizycznej. Co bardzo istotne, status konsumenta należy badać "na moment" dokonywania tej czynności prawnej. Stwierdzenie właściwego osadzenia w czasie działania danej osoby jest kluczowe dla prawidłowej oceny, czy przysługuje jej, czy też nie przysługuje status konsumenta. Zamiar strony, z którego wynika wykonanie danej czynności prawnej, należy oceniać tylko przez pryzmat faktów, okoliczności i zamiaru z daty dokonania tej czynności prawnej, ewentualnie z czasu poprzedzającego dokonanie tej czynności, jeśli z okoliczności wynika, że miały one wpływ na tę czynność prawną. Wszystkie okoliczności, jakie nastąpiły po wykonaniu czynności prawnej (zawarciu umowy), nie mają żadnego

${ }^{29}$ T. Sokołowski, Komentarz do art. $22^{1}$ k.c., pkt 2, s. 115. 
wpływu na status konsumenta (lub jego brak) w chwili wykonywania czynności prawnej (zawierania umowy). Istotny jest proces kontraktowania i sam moment dokonania czynności prawnej (najczęściej zawarcia umowy). Nieistotne są okoliczności dotyczące wykonywania umowy, gdyż nie ma możliwości, by w ten sposób utracić status konsumenta. Oczywiście, okoliczności, które wystąpiły w trakcie wykonywania umowy, mogą stanowić dowód, że intencje i zamiary konsumenta były inne niż deklarowane przy zawieraniu umowy. Moment czasowy analizy powinien być jednak zawsze i wyłącznie sprowadzony do daty wykonania czynności prawnej. Strona nie może post factum przez swoje działanie bądź zaniechanie ani stracić statusu konsumenta, ani się nim stać.

\section{THE LEGAL STATUS OF A CONSUMER AS A PARTY TO A LOAN AGREEMENT INDEXED TO THE SWISS FRANC}

\section{S u m m a ry}

In this study the legal status of a consumer as a party to the loan agreement indexed to the $\mathrm{CHF}$ is presented. During legal disputes, the subject of many controversies is the existence or the lack of the consumer status. This issue is of high procedural importance as it decides about the formal possibility of applying Article $385^{1} \S 1$ of the civil code (k.c.) and relying at the same time on the abusive nature of contractual clauses. In the article, the period that could be examined regarding the consumer status has been discussed in detail, indicating first of all that only the circumstances preceding the conclusion of the agreement and accompanying it influence the status of the consumer as provided under Article $22^{1}$ k.c. The status of the consumer exists in when the objective prerequisites defined in art. $22^{1}$ k.c. are fulfilled. The performance of the loan agreement has no direct influence on the issue and circumstances connected therewith and may be applied exclusively for the evidence purposes in the scope of facts and intentions of the natural person upon concluding the agreement. It was also raised that assessing or 'valuing' consumers due to the personal features (education, employment, practice) is not allowed and has no legal effect in the context of Article $22^{1}$ k.c. The pattern "of the enlightened consumer" having its justification in the scope of interpretation of Article $385 \S 2$ k.c. has no application to the interpretation of Article $22^{1}$ k.c. nor does the application of Article $385^{1}$ k.c. No features of a natural person prejudge either in plus, or in minus the status of the consumer. The fact that the property for which a loan has been taken out will be leased has no influence on the status of the consumer if the consumer being a natural person had a consumer status when concluding the agreement. Pursuant to the lex retro non agit principle the status of a consumer cannot be lost with retrospective force.

Keywords: consumer - consumer status - mortgage loan agreement - prohibited clauses 